\title{
Mocombeian Antihumanism
}

\author{
Paul CMocombe*
}

West Virginia State University, The Mocombeian Foundation, Inc., USA

\begin{abstract}
In the age of neoliberal (postindustrial) globalization social integration takes place, paradoxically, through the identity politics of postmodernism and poststructuralism on the one hand, and the continuous atomization of the human subject in (neo)liberalism on the other. This process, for me, is a continuation of the humanist ideology of liberalism and a humanist reactionism among previously discriminated against others seeking equality of opportunity, recognition, and distribution with their white liberal counterparts. In this work, I argue that the two aforementioned humanisms must be supplanted with an antihumanist philosophy, what I am calling Mocombeian antihumanism, which decenters human agential moments in the world to salvage it from self-annihilation in the age of climate change where global warming, pollution, resource exhaustion in late capitalist development threatens all life on earth.
\end{abstract}

\section{Keywords}

Ideological domination, Intersectionality, Antihumanism, Embourgeoisement, Black underclass, Black bourgeoisie, Social class language game, Dialectic, Antidialectic

The clarion call by discriminated against others, i.e., gays, women, blacks, transgenders, etc., around the world for recognition of their humanity, under concepts such as intersectionality, double consciousness, hybridity, etc., by their oppressors, is highly problematic in the age of climate change where global warming, resource exhaustion, and pollution in late capitalist development threatens all life on earth. That is to say, the (political) liberal humanism or human rights they (the discriminated against) want to be recognized under is "concerned to emphasize human welfare and dignity, and either optimistic about the powers of human reason, or at least insistent that we have no alternative but to use it as best we can" [1]. This humanist position dominates over all other conceptions of humanism and human rights: For examples, the Renaissance conception with its emphasis on the "rediscovery of the unity of human beings and nature, and a renewed celebration of the pleasures of life"; or the postmodern/feminist rejection of humanism, with its reliance upon "the possibility of the autonomous, self-conscious, rational, and single self", in favor of the "fragmentary, splintered, historically and socially conditioned nature of personality and motivation" [1]. The problem for me, which I call the humanist problem elsewhere, is that the first form of humanism (political liberal humanism) as encapsulated in the bourgeois concepts (the politics) of intersectionality, double consciousness, hybridity, feminism, etc., is contradictory, paradoxical, and oppressive [2]. There is a contradictory and oppressive conflict wherein the intersectional, hybrid, doubled, etc., bourgeois "others" seek equality of opportunity, recognition, and distribution, with their former white colonial masters/oppressors by convicting the latter for not applying their humanist values to the discrim- inated against intersectional, hybrid, doubled, etc., others who are, paradoxically, oppressed by the very humanist (economic) values they want recognized among them, which the whites/oppressors uphold for themselves while denying it for the "other." In other words, the discriminated against other wants to be recognized as an "other" with rationality and reason, like their white counterparts, for equality of opportunity, recognition, distribution. This despite the fact their desire perpetuates an "enframing" ontology, (economic) humanist (neo)liberalism, which threatens all life on earth through its exploitative (instrumental rational) practices, resource exhaustion, pollution, etc. Hence the two forms of humanism (economic and political liberal humanism) are contradictory and incompatible when it comes to the "other" seeking equality of opportunity, recognition, and distribution within (neoliberal) capitalism: In the political sphere, they seek to be recognized as an human other by recursively organizing and reproducing the human ideals of their oppressors for equality of opportunity, recognition, and distribution within the economic (neoliberal) sphere, which perpetuates and promotes resource exhaustion, pollution, global warming, oppression, and exploitation as keys to human welfare and dignity. I call this paradoxical condition the humanist problem [2].

*Corresponding author: Paul C Mocombe, West Virginia State University, The Mocombeian Foundation, Inc., USA

Accepted: October 31, 2020

Published online: November 02, 2020

Citation: Mocombe PC (2020) Mocombeian Antihumanism. Insights Anthropol 4(2):294-296 
In light of this humanist problem, I argue that in the age of postindustrial capitalism concepts such as intersectionality, hybridity, double consciousness, etc., are not revolutionary or counterhegemonic; instead, as promoted by the bourgeois "others" for social integration in the (neoliberal) Protestant ethic and the spirit of capitalism, they are reproductive, (post) modern, and fascist. In other words, they are ideological and absurd concepts used by the bourgeois "other" to interpellate (via ideological apparatuses such as education) and embourgeois their "other" counterparts and convict the white, capitalist, and patriarchal power structure for not living up to their universal (human) values. Humanist values recursively organized and reproduced by the intersectional other as they (the bourgeois "other") seek equality of opportunity, recognition, and distribution as an "other" within said power structure, which currently (via its universal humanist values, the intersectional other is convicting them for not universally practicing) threatens not only the other, with its centering of humanity and human (instrumental) reason to exploit the earth and other people for bourgeois dignity, wealth, and comfortability, but all life on earth [3]. Against this fascist attempt, in the form of identity politics, by the bourgeois intersectional other to interpellate everyone in contemporary (postindustrial) society to accept their embourgeois "otherness" within capitalist society in light of the deleterious effects (climate change, exploitation, oppression, pollution, environmental degradation, etc.) associated with bourgeois capitalist society, I call for an antihumanist practical consciousness, what I am calling Mocombeian antihumanism, which decenters the (bourgeois) liberal humanism of the oppressor and oppressed "other" for a naturalistic philosophy that speaks to the insignificance of being and the supremacy of nature, subsistence living, and reason and rationality as heuristic tools for understanding and experiencing existence.

\section{Background of the Problem}

Antihumanist discourse in social theory and philosophy is an attack on the liberal humanism of the Enlightenment. It is an historical, ideological, and metaphysical attack on traditional liberal humanism with its emphasis on essentialists concepts of humanity, human nature, and the ability of human reason to bring forth (rational) human progress in the world. Antihumanists, from Nietzsche to Marx, Heidegger, Althusser, and Frantz Fanon, criticize humanism as a metaphysical alternative (secular) form of theism that elevates the human being above all other species while, paradoxically, oppressing humanity with historical and ideological concepts or abstractions (human rights, freedoms to, justice, equality, etc.), grounded in or derived from either the mode of production or (scientific) reason and rationality, which are equated with the nature of reality as such.

Contemporary postcolonial, postmodern, and post-structural theories (intersectionality, gender liberalism, hybridity, etc.), building on the early antihumanist works of Nietzsche, Marx, Heidegger, Althusser, and Fanon, attempt to decenter the nature of the human being in traditional (liberalism) humanism by emphasizing the historical and fragmentary nature of identity. For the most part, through their own form of essentialism, they question, "the possibility of the autono- mous, self-conscious, rational, and single self", in favor of the "fragmentary, splintered, historically and socially conditioned nature of personality and motivation" [1]. This is a paradoxical move, however, in contemporary postindustrial capitalist societies.

That is to say, there is a contradictory and oppressive conflict in postindustrial (Protestant) capitalist societies wherein the intersectional, hybrid, doubled, etc., bourgeois "others", politically, seek equality of opportunity, recognition, and distribution, with their former white colonial masters/oppressors by convicting the latter for not applying their humanist values to the discriminated against intersectional, hybrid, doubled, etc., others who are, paradoxically, (economically) oppressed by the very humanist values they want recognized among them, which the whites/oppressors uphold for themselves while denying it for the "other." In a word, the "other" is, politically, seeking to be recognized as a liberal humanist despite the fact that, economically, the values of humanism, as highlighted by Theodor Adorno and Max Horkheimer [4] in the Dialectic of Enlightenment, themselves threatens their existence through capitalist oppression, exploitation, global warming, pollution, and resource exhaustion in the age of climate change.

\section{Theory and Method}

Instead of decentering both humanism and the fragmentary self, which is a simulacrum of the liberal humanist, the other, contemporarily, upholds them to convict and integrate bourgeois society. In other words, on the one hand, neoliberal globalization (1970s-to the present) represents the rightwing attempt to homogenize (converge) the nations of the globe into the overall market-orientation, i.e., private property, individual liberties, and entrepreneurial freedoms, of the capitalist world-system. This neoliberalization project is usually juxtaposed, on the other hand, against the narcissistic exploration of self, sexuality, and identity of the left, which converges with the neoliberalizing process via the diversified consumerism of the latter groups as they seek equality of opportunity, recognition, and distribution with agents of the former within their market logic. Hence private property, individual liberties, diversified consumerism, and the entrepreneurial freedoms of the so-called marketplace become the mechanism of system and social integration for both groups in spite of the fact that the logic of the marketplace is exploitative and environmentally hazardous.

The "other" power elites would emerge within this sociopolitical economic structure of the neoliberal global framework as structurally differentiated "other" agents of the Protestant Ethic and the spirit of capitalism (politically) seeking equality of opportunity, recognition, and distribution with their white counterparts as either "other" right-wing conservatives or "other" left-wing identitarians amidst the (economic) deleterious effects (exploitation, pollution, climate change, consumerism, etc.) of the humanistic values they desire whites to live up to by recognizing their humanism. For me, antihumanism is the correct response to resolving the contradictions between the political and economic liberal humanism the other finds themselves navigating. What I 
am calling Mocombeian antihumanism does not offer another alternative conception/abstraction of the self to replace the humanist position as postmodern and post-structuralism do. Instead, I call for a decentering of humanity in favor of a centering or essentializing of nature. To salvage themselves and the world among the pathologies of liberal humanism, humanity in general and the other in particular must decenter human welfare and dignity for an emphasis on the superiority of nature, subsistence living, and human reason as a tool for maintaining balance and harmony between nature and existence.

\section{Discussion and Conclusions}

Unfortunately, postcolonial, postmodern, and post-structural theories are the academic and political discourses of globalization and postindustrial capitalist relations of production of the contemporary age. The ideological and absurd concepts, i.e., ambivalence, double consciousness, créolité, négritude, intersectionality, etc., developing from these theories represent the psychological pathologies and practical consciousness of the bourgeoisies of once discriminated against others within the (Protestant) capitalist world-system. As a result of the emergence of a post-industrial capitalism intent on allowing divergent meanings and individual experiences, which were once discriminated against, to emerge around their class positions for use and exchange value and capital accumulation (diversified consumerism) in a service/ financial economy focused on entertainment and financial service, non-class meanings and subjective/individual experiences, homosexuality, transgenderism, black feminism, etc., which were, and to some extent continue to be, discriminated against by both the working/underclass and bourgeoisie of earlier capitalist relations of production are fostered and allowed to emerge within the dialectic of the global (postindustrial) capitalist social class structure or relations of production. These non-class meanings and subjective experiences, homosexuality, black feminism, Pan-Africanism, etc., practical consciousnesses, i.e., standpoint theories, which (some) are both the product of structural differentiation and the deferment of meaning in ego-centered communicative discourse, contemporarily, are seeking equality of opportunity, recognition, and distribution within the dialectic of a postindustrial capitalist social structure that stratifies and commodifies these non-class (standpoints) identities, meanings, and subjective/ individual experiences around their class positions or social relations to production for capital accumulation in the service economies of core, postindustrial nations, such as the US, UK, etc. What has emerged, as a result, are these ideological and absurd theories of ambivalence, hybridity, créolité, négritude, double consciousness, bifurcated consciousness, and intersectionality among bourgeois academics of once discriminated against others highlighting the discourse by which these variant subjective positions have been alienated, marginalized, and prevented from achieving equality of opportunity, recognition, and distribution within the global (postindustrial) capitalist social structure of racial-class inequality and differentiation. Their theories and identities are reified, universalized, and extrapolated globally under the ideological umbrella of identity politics, the fight for social justice, truth, and love. However, by no means can these theories be viewed as the universal mechanism by which consciousnesses and communities were constituted. Their rhetoric are the by-product of the global (industrial and postindustrial) capitalist social structure of class inequality and differentiation and its ideological apparatuses, which attempts to interpellate and structure the practices of subjective experiences within class differentiation and thereby control the practices of diversity and meaning constitution, which contemporarily juxtaposes the bodies, language, ideology, and material conditions of a transnational, multiracial, multicultural, multisexual, etc., upper-class of owners and high-level executives against the bodies, language, ideology, and material conditions of a transnational, multiracial, multicultural, mulitsexual underclass in poverty the world-over seeking equality of opportunity, recognition, and distribution with the former amidst economic exploitation, pollution, and climate change brought about by the very universal human values they are seeking recognition for from whites who initially utilized these same values to oppress them. Hence, the postmodern, post-structural, post-colonial theories of ambivalence, hybridity, créolité, négritude, double consciousness, and intersectionality are the concepts, psychological processes, pathologies, and practical consciousness of the bourgeoisies of the once-discriminated against. They are standpoint theories that do not offer an alternative form of system and social integration to the global Protestant capitalist social structure of class inequality. They simply seek to convict the initial power elites (rich, white, heterosexual, men) of the system for not identifying with their values in order to achieve equality of opportunity, recognition, and distribution. As such, their theories do not speak to the nature of identity constitution in general; instead, it speaks to one aspect of identity constitution, i.e., structural reproduction and differentiation within postindustrial (Protestant) capitalist relations of production amidst its deleterious problematic, i.e., climate change, which is not address by identitarianists and their absurd fight for equality of opportunity, recognition, and distribution within the latter, which threatens all life on earth. To salvage themselves and the world among the pathologies of liberal humanism, humanity in general and the other in particular must decenter human welfare and dignity for an emphasis on the superiority of nature, subsistence living, and human reason as a tool for maintaining balance and harmony between nature and existence.

\section{References}

1. Blackburn S (1994) The Oxford Dictionary of Philosophy. Oxford University Press.

2. Mocombe Paul (2012) Liberal bourgeois protestanism: The metaphysics of globalization. Studies in Critical Social Sciences (Vol. 41). Brill Publications, Leiden, Netherlands.

3. Giddens Anthony (1990) Consequences of Modernity. Polity Press, England.

4. Theodor Adorno, Max Horkheimer (1944) The Culture Industry: Enlightenment as Mass Deception. 